\title{
Whats and Hows? The Practice-Based Typology of Narrative Analyses
}

\author{
Grzegorz Bryda \\ CAQDAS TM Lab \\ Institute of Sociology \\ Jagiellonian University
}

DOI: http://dx.doi.org/10.18778/1733-8069.16.3.08

\begin{abstract}
Keywords: Narrative Analysis, CAQDAS, Content Analysis, Text Mining, dictionarybased coding, topic modeling
\end{abstract}

\begin{abstract}
The nature of qualitative research practices is multiparadigmaticity which creates coexistence of different research and analytical approaches to the study of human experience in the living world. This diversity is particularly observed in the contemporary field of narrative research and data analysis. The purpose of this article is a methodological reflection on the process of developing typology and a proposition of new data-driven and practice-based typology of narrative analyses used by qualitative researchers in the lived experience research. I merge the CAQDAS, Corpus Linguistics, and Text Mining procedures to examine the analytical strategies inherited in a vivid language of English-language research articles, published in five influential qualitative methodological journals between 2002-2016. Using the dictionary-based content analysis in the coding process, hierarchical clustering, and topic modeling - a text-mining tool for discovering hidden semantic structures in a textual body - I confront Catherine Kohler Riessman's heuristic typology with the data-driven approach in order to contribute the more coherent image of narrative analysis in the contemporary field of qualitative research. Finally, I propose a new model of thinking about the typology of narrative analyses based upon research practices.
\end{abstract}

Grzegorz Bryda, Assistant Professor at the Institute of Sociology of the Jagiellonian University, Head of the CAQDAS TM LAB and the Summer School for Qualitative Data Analysis and Research Methods. Senior Consultant for Statistical Analysis and Data Mining and Lecturer at the Training Center of SPSS Polska (currently IBM Predictive Solutions, 2003-2009). Rector's Proxy for the Evaluation System of Quality Assurance (2008-2017). He is interested in Methodology of Qualitative Research, Innovations in CAQDAS and Qualitative Data Analysis, Textual and Narrative Analysis with NLP and Text Mining, Digital Humanities and Social
Science Computing, Cognitive Sociology, and Corpus Linguistics Analysis. He is working on a pioneering project: 'From Paradigm to the Research Method: The Domain Ontology as a Model of Knowledge Representation About the Contemporary Field of Qualitative Research.'

\section{Contact details:}

CAQDAS TM Lab, Institute of Sociology

Jagiellonian University,

31-044 Kraków, ul. Grodzka 52

email address: grzegorz.bryda@uj.edu.pl 


\section{Narrative as a mode of knowing}

A narrative is a pervasive form of communication in the social world. In sociology, the word 'narrative' is used to provide an accessible way to understand the lived experience, events, and processes that scholars witness every day. 'Narrative' means telling a story, describing a series of events, and explaining something according to a particular way of understanding events. In social sciences, a narrative is connected with notions such as life, auto/biography, hi/story, identity, storytelling, experience, interview, analysis, inquiry, or research. Narrative research or inquiry is a flexible and accessible approach in the exploration of lived experience and the process of identity re/construction. Lived experience, narrative approach, and meaning analysis a real crucial concepts for reaching a deeper understanding of a participant's perspective, thus improving the qualitative comprehension in the study of social and psychological phenomena. 'Narrative research,' in turn, is a broad term for a group of approaches that focus on the written, spoken, or visual representation of life stories of individuals. In qualitative research practices, lived experience is explored and understood in various ways (Elliott 2009). Researchers in social sciences and in humanistic disciplines collect and study people's narratives that exist as oral hi/stories, auto/ethnographical or auto/biographical writings (diaries, letters, books), spoken or written personal testimonies, photographs, audio recordings, movies, and in other narrative data forms. Social research has a long tradition in using qualitative methods to gain an insight into people's lives and to understand the meaning that people attach to their personal experience. When using a narrative approach, a social researcher tries to recognize how people "story the world" in order to contribute an understanding of how they create meaning and what those stories convey, and how (Mishler 1995:117). The narrative has become a buzzword among social scientists in recent years, and storytelling is a common technique of gathering information about people's lived experience. Everything that surrounds human beings socially, environmentally, or physically (nature, everyday conversations, the Internet and new technologies, music, photographs, or movies); everything one reads, hears, or sees - all this comprises stories. This is what many social scientists refer to as the 'narrative turn' (Polkinghorne 1988; Czarniawska-Joerges 2004; Kreiswirth 2005). Some authors claim that narratives have their origins in narratology, hermeneutics, structuralism, and literary tradition, including content and discourse analysis. On the other hand, the narrative turn is perceived as an effect of emergent postmodern discussions on the relationships between self, the other, community, personal identity, social, as well as cultural, political, and historical dynamics. It also includes questioning the positivist approach in examining the social world and understanding human experience and activity. For many qualitative researchers, the narrative research approach is a natural way of speaking about human social life.

This paper is not only a methodological reflection on the contemporary analytical approaches used in narrative research of lived experience; it is also a proposition of practice-based typology of those approaches. I am looking for an answer to the question about how qualitative researchers analyze narrative data. What kind of approaches do they adopt in exploring and discovering the meaning of lived experience? How do they think about narrative analysis? Do they use the contextual (paradigmatic, thematic) or the structural (syntagmatic, linguistic) approach in narrative analysis? My considerations are based on the bottom-up, data-based approach, 
which is a combination of CAQDAS, Content Analysis, and Text Mining procedures. I use the Natural Language Processing algorithms in key narrative analysis phrase extraction, the CAQDAS and Content Analysis dictionary-based coding (Bryda 2014a; Bryda and Tomanek 2014), and a hierarchical clustering and topic modeling, which are text-mining tools for discovering hidden semantic structures in a textual corpus (Cheng 2012). This new approach to the typology of narrative analysis is a part of the bigger research project on domain ontology as knowledge representation about qualitative research practices (Bryda and Martini 2016; Bryda 2020). ${ }^{1}$

\section{What is Narrative Analysis?}

The concept of narrative analysis, inspired by social constructionism, is currently one of the most popular and widely used terms in the social and human sciences. In social sciences, the concept of narrative research and analysis is connected with the development of subjectivity and individual or collective identity. It also examines superstitions, stereotypes or prejudices: ethnic, cultural or gender-related. Narratives as a way of constructing identity are studied in the context of social interactions and analyzed using methods from the intersection of sociology, psychology, and applied linguistics (Mehdi 2016). In sociological and sociolinguistic traditions, narrative research and analy-

${ }^{1}$ The aim of this project is to articulate these practices in a legible system of knowledge representation while employing the information concept of domain ontology. In the process of building the ontology of the contemporary field of qualitative research practices, I link know-how drawn from the sociology, social science computing, NLP, and text mining, as well as digital humanities and corpus linguistics. The ways that the qualitative research practices discover are conceptualized and represented in the vivid language of scholarly articles, all this when taking into account the problem of a "curse of abundance" in the present-day field of qualitative research. sis is represented by four modes of thinking which have been developing since 1960 (Cortazzi 1993). Two of them are strictly embedded in ethnomethodology. When narratives occur in natural oral settings, they can be examined from the perspective of Conversational Analysis. Researchers who use this approach try to discover interactional patterns in the conversational context of narratives. They analyze a given talk in order to understand how participants view their lifeworld, how casual, daily conversations are structured, how this orderliness comes about and what kind of social knowledge people need to tell a story in the course of a conversation. The second model of narrative analysis is based on Erving Goffman's idea of Frame Analysis. Goffman (1975) used a dramaturgical metaphor to draw parallels between the stage and conversation in order to show how people organize face-to-face interactions. Making sense of any social situations is being done by constructing meaning through frames of understanding. Frame analysis is underpinned by the idea that people have to classify their experience if they are to grasp its significance and communicate it to fellow human beings. In frame narrative analysis, one is looking for any narrative comments in the context of dramaturgical model of face-to-face interactions. The third evaluation model of narrative analysis comes from William Labov and focuses on the internal, formal structure of narratives in relation to their social functions (in a sociolinguistic context). Labov and his colleagues developed particular interview questions in their sociolinguistic research in order to overcome the formal constraints of face-to-face interviews (Labov and Waletzky 1967). More casual and natural speech was obtained where speakers were personally involved in what they were saying. In the beginning, in Labov's model of narrative analysis, the informal speech styles of narrative have 
been correlated with different social variables. Later, narratives were analyzed in their own right in terms of their structure and social function, which were correlated with the age, social class, and ethnicity of the respondents (Labov 1972). The emphasis on the social context of the narratives is also developed in the model of narrative analysis in the work of Nessa Wolfson (1976) and Livia Polanyi (1985). They link narratives with culture and performativity, especially with the context of interview as a way for eliciting narratives.

\section{Riessman's typology of narrative analysis}

In literature, there are a lot of various typologies of narrative analysis (Mishler 1995; Cortazzi 2001; Elliot 2009; Clandinin and Rosiek 2007; Kohler Riessman 2008; Phoenix, Smith, and Sparkes 2010) as well as its applications (Kohler Riessman 1993; 2008; Andrews et al. 2004; Herman and Vervaeck 2005; Holstein and Gubrium 2012; De Fina and Georgakopoulou 2015 ). Moreover, the methodological research design suggests different methods of carrying out narrative analysis (Czarniawska-Joerges 2004; Coulter and Smith 2009). The most popular and pragmatic typology of narrative analysis in social sciences -one that is especially useful for analyzing oral stories of personal experiences has been proposed by Katherine Kohler Riessman (2008). This typology is based on the heuristic distinction between four ways of handling and analyzing narratives: thematic, structural, dialogic/ performative, and visual.

In thematic analysis, the emphasis is on the content of oral and written narrative data, the meaning, and the interpretation of what is being said. The focus is on what is said more than on how it is said. Language is an unequivocal and direct way to discover the meaning of what has been said. It is a resource, not an object of study; a way of representing the world that is the subject of the story. The context of what is being said is not usually the central point of narrative analysis. The thematic approach is useful for theorizing with regard to many cases. One pays attention to discovering themes and similarities (what is common) between analytical cases: the respondents and their experiences or events. One wants to combine many narratives into similar categories (codes, concepts, themes) as well as create typologies concerning the inductively developing theory. However, typologies can be ways of representing knowledge about the living world. The thematic narrative analysis is partly similar to the Grounded Theory approach, but Riessman points out that while both the narrative and the grounded theory come up with themes, they differ from each other. Narrative analysis is case-centered more than focused on theorizing across cases.

In structural analysis, the focus shifts to the way in which stories are told. The focus is on the form, i.e. on how one speaks and how language is used in the narrative. The way the narrator chooses the individual "narrative devices" (linguistic means) is what tells the story. Contrary to how it is with the thematic approach, the narrative language is the actual subject of the analysis - the object of study apart from having a referential function. ${ }^{\circ 2}$ Structur-

\footnotetext{
${ }^{2}$ One of the first narrative-analysis methods was developed by William Labov and his colleagues. They analyzes the structural function of the clause in the whole narrative, and how the communication that it performs works. Labov modified this approach to the study of first-person relationships about violence - short, thematically focused and time-ordered stories - but retained the basic elements of the narrative structure: an abstract (summary and/or point of history); orientation (to time, place, form, and situation); complicating the action (sequence of events or plot, turning points); evaluation (the comments on the meaning and conveying emotions); resolution (plot result); and Koda (ending the story and
} 
al analysis requires the study of syntactic and prosodic features of the language. Riessman believes that this approach is rather useful for detailed microanalysis of small number of cases or for comparing several narratives, such as in Labov's and James Paul Gee's studies (Labov 1972; Gee 1991). ${ }^{3}$ Microanalysis allows for developing theories that relate to language and meaning. In the process of preparing data for analysis, depending on the purpose of the project, the researcher must specify a transcription accuracy of the interview. However, some excerpts from the interview can become illegible to people who are unfamiliar with sociolinguistics. As with the thematic approach, strict adherence to structural analysis procedures can lead to the decontextualization of the narrative, thus ignoring historical, interactive, and institutional factors. At the same time, methodological assumptions and research procedures limit what can be told and shape the way in which a given narrative or story develops. This approach to narrative analysis requires a careful study of the narrative structure itself, which on the one hand can generate a new perspective on the narrative construction process, but, on the other, is a complicated procedure of analysis which requires some linguistic knowledge.

In dialogic/performance analysis, one focuses on the context and views narratives as a multi-voiced

transferring the action to the present) (Labov 1991). Of course, not all stories contain all elements and the might occur in different sequences. Labov's microanalysis convincingly shows how violent actions (in bars, on the street, etc.) are the result of unsuccessful speech acts. Based on a small set of narratives and Erving Goffman's works, he develops a theory of request rules that explains the violent outbursts in various circumstances, experienced by a diverse group of narrators.

${ }^{3}$ Gee's method of narrative data organization would be best for exploring the role that language plays in narrative construction, whereas Labov's method would be more ideal for examining a certain event and its effect on an individual's experiences. and co-constructed reality. The emphasis is on dialog, i.e. a contextually-embedded interaction between the narrator (respondent) and the listener (moderator). One goes beyond the spoken word. Storytelling is seen as a performance -Self and the past, Self and the Other - which engages the audience through language, gesture, and meaning. The narrative is about 'doing,' not only telling oneself with different performative approaches (psychosocial drama, storytelling, autoethnographic writing, etc.) to the narrative as a social practice. Analyzed stories of experience usually appear in specific situational contexts (work, medical care, social assistance, court situations, etc.), but both the content and structure of the narrative are important; the researcher's interest shifts to the fact of telling a story as a process of constructing meaning by the speaker and the listener alike. Stories are contained in the structure of questions and answers, and organized around daily experiences and events. Therefore, it is very important to include factors such as linguistic markers and story sequence in the transcript of a given conversation. As it is in conversation analysis, a transcript includes para-lingual and performative interaction features. The dialogic/performance narrative analysis is useful for studying relationships between speakers and listeners in different environments: courts, schools, classrooms, organizations, psychotherapy offices, and the interview itself. It emphasizes how different contexts - linguistic, historical, and sociocultural - influence the performance of narrative and the process of lifeworld construction.

Lastly, in visual narrative analysis approach one attends not only to how and why visual objects(photographs, collages, paintings, movies, or video diaries) are produced, but also to how they are made by the participants or in a kind of collaboration. 
The main point of visual narrative analysis is the process of production of images, i.e. visual objects. The focus is on the image itself and the different ways of making interpretations which are given to each image. The key element of this approach is the statement that images 'found' in fieldwork (e.g. photographs, movies, paintings) and 'made' during the research (e.g. self-portraits, vlogs, video diaries) can be a story or tell a story. Therefore, images should be treated in the same way as spoken or written narratives. Images do not just 'speak for themselves'; ultimately, in the interpretation process, they must be contextually grounded and understood. Because of the visuality of images, narratives can be interpreted in various ways by different people as well as differently constructed by both the participant and the researcher.

In qualitative research practices, these approaches are not mutually exclusive, but the value, as Riessman notes, is their emergent combinations depending on research problems. Those combinations are conducive to the formation of a more complete picture of narrative analysis. Taking into account the classical heuristic approach, it is really problematic to provide a single definition of what narrative analysis is. Narrative analysis exists more as an umbrella term which covers different analytical methods of handling a spoken, written, and visual narrative (Kohler Riesmann 1993). Despite this plurality of analytical approaches, most of narrative researchers share a basic understandings of what narrative analysis is. The examination of this plurality helps one better understand what narrative analysis is and what the dimensions and relationships are among the analytical strategies used in different narrative studies. Finally, it provides a better insight into what kind of narrative analysis is done, and how.

\section{Methodology}

The examination of narrative data analysis approaches that I would like to carry out is a part of a bigger research project titled 'From Paradigm to the Research Method: The Domain Ontology as a Model of Knowledge Representation About the Contemporary Field of Qualitative Research' (Bryda and Martini 2016; Bryda 2020). ${ }^{4}$ The primary aim of this study is to create a model representing up-to-date knowledge about qualitative research and analytical practices, i.e. the activities by which qualitative research designs are manifested. This model is rendered in the form of a legible scheme of ontological, epistemological, and methodological classification of ways by which qualitative data is collected, analyzed, and interpreted. I am looking for connections and relations among paradigms, methodological trends, methods, and techniques of collecting and analyzing data, which manifest in the vivid language of articles from mainstream journals. It will encompass a comprehensive catalog of up-to-date variations in qualitative research practices, their variants, and methodological configurations. ${ }^{5}$ This model is based upon the con-

\footnotetext{
${ }^{4}$ This project is funded by the Polish National Science Centre (Competition: OPUS 12; Panel Description: HS6_13: Theoretical sociology, methodological orientations and variants of empirical research). The project duration is 2017-2020.

5 The term 'ontology' can refer to different structures of knowledge and, hence, certain ontological divisions. The most fundamental are the universal (base) ontologies - including core concepts of scientific knowledge - versus the limited (domain) ontologies, which describe a slice or piece of reality within a select range of knowledge. Due to the degree of formalization, also distinguished are informal ontologies developing on the basis of predefined vocabularies, dictionaries, thesauri, and taxonomies versus formal ontologies grounded in data structure or logic (Munn and Smith 2008). As a means by which the semantic space of knowledge representation is represented, domain ontology supports scholarly communication between researchers and facilitates the formation of a coherent means of expressing its problematics. A consequence of the creation of domain ontology is a knowledge-based development that allows for the monitoring of
} 
cept of domain ontology, known from the field of knowledge engineering. It can be used as a communication platform for the development of methodological knowledge between scholars who utilize different qualitative methods of data collecting and analyzing, and can lead to the enhancement of transparency of procedure in qualitative research and analysis. ${ }^{6}$

The Domain Ontology project's methodology - as well as the new typology of narrative analysis - is the combination of know-how from social sciences, especially CAQDAS (Kelle 1995; Fielding and Lee 1998; Lewins and Silver 2007; Bryda 2014b), Digital Humanities, Corpus Linguistics (McEnery and Hardie 2011; Cheng 2012), Natural Language Processing, and Text Mining (Feldman and Sanger 2007). The process of discovering the typology model of narrative analysis is facilitated by mixed methodology (Tashakkori and Teddlie 1998; Col-

trends in a given field's theory and methodology; this, in turn, becomes the foundation for knowledge-based qualitative empirical research.

6 The field of contemporary qualitative research and data analysis practices is, quite naturally, accompanied by exceptional creativity in the data analysis and research methodology domain (Creswell 1998; Flick 2014; 2018). This means that the drawing-up of a consistent and coherent image of the field of qualitative research and analytical practices is a really difficult task. Nevertheless, a need for orientation in the field of one's own research practice leads one to undertake an attempt to reduce the complexity. In the project, we do an examination of numerous individual acts of qualitative research practice which help to distinguish some patterns of research and analytical behavior. The domain ontology project tackles the problem of a "curse of abundance" in the field of contemporary qualitative research (Denzin and Lincoln 2011). The goal is to systematize the current state of affairs with regard to qualitative research practices and rein in the diversity of its variations. Alongside this goal is an intention to assemble a comprehensive catalogue of the fundamental building blocks and their configurations in qualitative research today. Unique testimonies of research experience will be drawn together to form a clear, legible whole. This project is a significant contribution to the development of methodological knowledge in the field of qualitative research as its outcomes will be applicable both in practice and teaching. lins, Onwuegbuzie, and Jiao 2007; Creswell 2015). The analytical design is based upon the idea of knowledge discovery in textual corpora with data extraction procedures used in Natural Language Processing and Text Mining (Berry 2004; Leetaru 2012; Ignatow and Michalcea 2016). Moreover, I am combining computer-assisted qualitative data analysis approach (Dey 1993; Kelle 1995; Bong 2002) with the procedures of content analysis and dictionary-based coding (Berelson 1952, Mayring 2000; Krippendorf 2004; Bernard and Ryan 2010; Schreier 2012).

\section{Textual corpus}

In order to explore strategies of narrative data analysis, I decided to examine English-language articles published between 2002-2016 in five influential qualitative methodological journals: The Qualitative Report (TQR, est. 1990), Qualitative Inquiry (QI, est. 1995), Forum: Qualitative Social Research (FQS, est. 2000), Qualitative Research (QR, est. 2001), and International Journal of Qualitative Methods (IJQM, est. 2002). These periodicals have been selected for the textual corpus due to their positioning in the milieus of qualitative researchers around the world; this is evidenced by their high Impact Factor as well as their transdisciplinary character. However, because of their relatively brief publishing cycle, journals react much faster to changes taking place in the field of qualitative research and data analysis, and, therefore, they facilitate the distinction of tendencies as yet unsanctioned by tradition and methodological books. These articles convey representations of various conceptualizations and implementations of different approaches in narrative analysis, including those which - due to their novelty or exceptionality - do not (yet) belong to the canon of those analyses. 
The textual corpus analyzed in this paper has been separated from a broader corpus ${ }^{7}$ used in the project of domain ontology. ${ }^{8}$ Reviews, editorial introductions, sets of abstracts, post-conference notes/ papers, publishing reports, essays, and poems have been excluded from the textual corpus, and only traditional articles were included. After the selection, the articles were described by the following variables (meta descriptors): article id, author, year of publication, source (journal title), type of article, the fact of the occurrence of the keywords, the fact of abstract occurrence. In next steps, textual corpus was analyzed and reduced with the QDAMiner and Wordstat software. I started this process from the initial review of articles with distance reading and content analysis in order to find some linguistic (grammatical) criteria based on the word/ phrase collocations. I was looking for some selection criteria relating to narrative analysis and lived experience. I used two linguistic techniques: word sketch (to find collocations with words as well as word combinations) and multiword sketch (to find collocations with phrases). The word sketch processes the words, collocates, and other words in its surroundings. It produces the word's grammatical and collocational summary. The results are organized into categories, called grammatical relations (words that serve as an object of the verb, words that serve as a subject of the verb, words that mod-

\footnotetext{
7 A corpus (plural: corpora) is a collection of analyzed texts that we use for language research (and in corpus linguistic analysis). Corpora are used as a basic tool in language, literature, and culture research. For linguists, translators, dictionaries, and language textbooks are an indispensable work tool. In sociology - especially in qualitative research and data analysis - corpora thinking is a rather new approach. In the content analysis, the corpus is merely a collection of textual data. However, there are a lot of comparisons between a linguistic analysis and a qualitative sociological data analysis, which can be effectively used in creating a new way of thinking about narrative analysis.

8 The original textual corpus used in the Domain Ontology project contains 6500 articles published between 1990-2018.
}

ify the word, etc.). The words which were included in the narrative analysis were defined by rules written in the sketch grammar. The multiword sketch is an extension of the word sketch. It processes the left and right context of a phrase and identifies the collocates of each word in the phrase. ${ }^{9}$ Collocations are only extracted from sentences which contain the particular collocation. I tested some collocations in my textual corpus. Finally, I checked collocations for words such as: narrative, research, analysis, experience. I looked at their combinations in the statement or paragraph context. I decided to choose articles with phrases such as: narrative analysis, narrative research, adjectival and nominal description of lived experience. They were used as language indexes (markers) in selecting the article about narrative analysis, but the phrase had to always be present in the analyzed texts. I gathered 400 articles as the textual corpus, and I started next selection step, namely a close reading. After all these linguistic data transformations and the distance and close reading, my final textual corpus contained 350 fully checked articles. Moreover, articles were converted into raw text and all editorial references, graphics, footers, and headings containing publishing data have been removed. This data cleaning and preparation procedure is necessary, because the unordered data can cause information chaos and hinder the correct application of corpus linguistics and text mining analysis procedures. A detailed summary of the number of articles according to the source and year of publication is shown in Table 1.

\footnotetext{
${ }^{9}$ I used the Sketch Engine software for the word and phrase extraction. This is the ultimate tool to explore how language works. Its algorithms help one to analyze authentic textual corpora in order to identify instantly what is typical in language and what is rare, unusual or emerging usage. It is also designed for text analysis or text-mining applications. The sketch word and sketch multiword are both implemented into the Sketch Engine.
} 
Table 1. Number of articles by source and year of publication

\begin{tabular}{|l|l|l|l|l|l|l|l|l|l|l|l|l|l|l|l|l|}
\hline & $\mathbf{2 0 0 2}$ & $\mathbf{2 0 0 3}$ & $\mathbf{2 0 0 4}$ & $\mathbf{2 0 0 5}$ & $\mathbf{2 0 0 6}$ & $\mathbf{2 0 0 7}$ & $\mathbf{2 0 0 8}$ & $\mathbf{2 0 0 9}$ & $\mathbf{2 0 1 0}$ & $\mathbf{2 0 1 1}$ & $\mathbf{2 0 1 2}$ & $\mathbf{2 0 1 3}$ & $\mathbf{2 0 1 4}$ & $\mathbf{2 0 1 5}$ & $\mathbf{2 0 1 6}$ & TOTAL \\
\hline TQR & 1 & 1 & 1 & 2 & 1 & 4 & 3 & 6 & 10 & 8 & 12 & 14 & 10 & 6 & 16 & 95 \\
\hline FQS & 3 & 9 & 2 & 2 & 4 & & 12 & 11 & 7 & 6 & 7 & 7 & 5 & 12 & 5 & 92 \\
\hline QI & 3 & 2 & & 5 & 5 & 4 & 9 & 7 & 1 & 10 & 7 & 7 & 7 & 2 & 4 & 73 \\
\hline QR & 2 & 2 & 1 & 2 & & 1 & 7 & 8 & 6 & 4 & 3 & 3 & 3 & 5 & 3 & 50 \\
\hline IJQM & 4 & 1 & 3 & 1 & 3 & 2 & 1 & & 3 & 5 & 5 & 6 & 3 & 2 & 1 & 40 \\
\hline TOTAL & 13 & 15 & 7 & 12 & 13 & 11 & 32 & 32 & 27 & 33 & 34 & 37 & 28 & 27 & 29 & 350 \\
\hline
\end{tabular}

Source: Self elaboration.

\section{CAQDAS and Corpus Linguistics}

The next analytical step is the process of phrases extraction and coding. I decided to apply an analytical framework which combines computer-assisted qualitative data analysis with corpus linguistics and text mining methodology. Corpus linguistics is as a methodology for "studying language use" (McEnery and Wilson 2001; Bowker and Pearson 2002; McEnery and Hardie 2011). It helps to discover how language is used today and how that language is used in different contexts. Corpus linguistics emerged in the humanities, but it is not a branch of linguistics in the same sense as syntax, semantics, sociolinguistics, etc. It is a part of the rapidly evolving discipline of Digital Humanities (DH), the study of language with usage of new technology as it is expressed in textual corpora, as evidence of the "real world."10

\footnotetext{
${ }^{10}$ As we know from the Analytical Philosophy studies, there is a relationship between language and action as well as language and cognition. So, if I assume that language is a representation of the cognitive structure, I can assume that the vivid language of written articles is a representation of qualitative research practices and analytical practices. This
}

It proposes that reliable language analysis is more feasible with corpora collected in the fieldwork in its natural context and with minimal experimental interference. A corpus-based linguistic approach as a part of Corpus Linguistics can be effectively developed in the field of qualitative research, especially in narrative research. This methodology is similar to the CAQDAS methodology, particularly to data-based approach that characterizes Grounded Theory. For example, text annotation consists of structural markup, part-of-speech tagging, parsing, lemmatizing, disambiguation, and numerous other text representations are similar to the coding procedures, consisting of close text reading, open, focused, and theoretical coding, categorization, thematizing, etc. Linguistic abstraction consists of the translation (mapping) of terms in the scheme into terms in a theoretically motivated model or dataset. It includes linguist-directed search but can include e.g. rule-learning for parsers. In the CAQDAS analysis, one search-

is a new, interdisciplinary approach which sets out a new subfield in the methodology of computer-assisted qualitative data analysis. 
es for codes, categories, themes; there is a merge of quotations, parts of texts, writing memos; mental, semantic or cognitive mapping is used as well as comparison methods are applied to look for patterns. The last is the process of data analysis. Linguistic analysis consists of statistical probing, manipulating, and generalizing from the dataset, and might include some statistical evaluations, optimization of rule-bases, or knowledge discovery methods. The CAQDAS analysis is based on looking for similarity and patterns in data. Diagrams, schemes, tables, paths, and networks are used to show relations and dependencies in analyzed data (Fielding 2012). Some CAQDAS software (i.e. QDAMiner and Wordstat, Rapid Miner) use more sophisticated analysis, such as the Correspondence Analysis, Sequential Analysis, or Factor Textual Analysis. Some traditionally statistical model of analysis is gradually fixed into the CAQDAS software (i.e. NVivo, Maxqda). This is because computer-assisted data analysis is embedded in the rapidly developing field of textual analysis. A lot of new methodological innovations in CAQDAS - such as corpus-based or dictionary-based approach - come from Corpus Linguistics, Content Analysis, and Text Mining. They link words'/phrases' linguistic extraction with qualitative coding and searching procedures.

\section{Dictionary-based coding}

The use of corpus-based dictionary approach in examining the strategies of narrative analysis extends and enriches a traditional qualitative data analysis. Going beyond simple coding and searching procedures used in the CAQDAS and Content Analysis, I apply automatic dictionary-based method of textual data handling (keyword or key-phrase classification), although coded content is verified by the research- er. ${ }^{11}$ The use of a dictionary helps to search (and do linguistic extraction), code (annotate), and analyze different textual passages in a corpus, which would be difficult to achieve using the classical CAQDAS or content analysis. The linguistic corpus-based coding dictionary is a similar tool to the codebook in CAQDAS, or a categorization key in content analysis. Contrary to the codebook and the categorization key, the coding dictionary is equipped with syntactical and grammatical language rules in which the content is being searched (Tomanek and Bryda 2014). I started the process of building the linguistic coding dictionary by carefully reading and reviewing articles; a list of keywords and key-phrases was obtained by using the word sketch and multiword sketch extraction. I used the Sketch Engine and Wordstat software to extract phrases. I assumed that all extracted phrases or collocations in the corpus had to be connected with - or be indicators of - the analytical strategies used in narrative studies. Moreover, they have to be the proper names, or closely related to narrative analysis. They were applied to compile the linguistic coding dictionary of narrative analysis. I used the QDAMiner and Wordstat software in order to create, verify, and test the final version of the linguistic dictionary of narrative analysis. Ultimately, I found twenty-six types of narrative analysis occurring in the textual corpus. For further analysis, I created main categories-according to Riesmann's typology - merging those types of narrative analysis with the four types: thematic, structural, dialogic/performance, and visual (see Chart 1). Moreover, I decided to add the mixed-methods approach as an extra category.

\footnotetext{
${ }^{11}$ I do not make here a distinction between qualitative and quantitative approach to Content Analysis, because normally I use them both as my analytical framework. I merge the bottom-up and to top-down analytical approaches, especially in extracting, searching, and coding procedures by means of doing semi-automated content analysis (Hopkins and King 2010).
} 
Chart 1. The Linguistic Coding Dictionary of narrative analysis

\section{Thematic}

Thematic analysis

GTM analysis

Content analysis

Metaphor analysis

Hermeneutic analysis

Comparative analysis

Secondary analysis

\section{Structural}

Structural analysis

Network analysis

Taxonomic analysis

Linguistic analysis

Discourse analysis

Sequential analysis

Conversation analysis

\section{Dialogic/performance}

Interaction analysis

Biographical analysis

IPA analysis

Case analysis

Collaborative analysis

Vignette analysis

Performative analysis

Frame analysis

Dialogic analysis

Visual

Visual analysis

Mixed method

Semiotic analysis

Mixed-method analysis

Source: Self elaboration.

Finally, I used this dictionary to code the paragraphs and to check what types of analysis are used primarily in narrative research practices described in the articles (see Table 2).

Table 2. Riessman's types of narrative analysis

\begin{tabular}{|l|l|l|l|l|l|}
\hline \multicolumn{1}{|c|}{ TYPE OF ANALYSIS } & FREQUENCY & \% SHOW N & NO.CASES & \% CASES & TF ・ IDF \\
\hline Thematic & 456 & $37,81 \%$ & 141 & $40,29 \%$ & 180,1 \\
\hline Structural & 429 & $35,57 \%$ & 97 & $27,71 \%$ & 239,1 \\
\hline Dialogic/performance & 205 & $17,00 \%$ & 89 & $25,43 \%$ & 121,9 \\
\hline Mixed method & 83 & $6,88 \%$ & 37 & $10,57 \%$ & 81 \\
\hline Visual & 33 & $2,74 \%$ & 14 & $4,00 \%$ & 46,1 \\
\hline
\end{tabular}

Source: Self elaboration.

Qualitative scholars use in their research designs mainly two approaches: the thematic and the structural analysis. It means that they focus in their analysis on discovering the meaning of the story (content) and on the way the story is being told (form). From the table one can see that narrative analysis is more textual than visual. Moreover, it is interesting that the mixed-method approach - which was not included in Riessman's typology - is integrated in the articles.

\section{Results}

In corpus linguistic, content and text mining analyses, an important element of results interpretation 
is the TF-IDF measure (term frequency-inverse document frequency). The TF-IDF is intended to reflect how important a word or a phrase is to a document in a corpus. It is often used as a weighting factor in information retrieval and text mining. The TF-IDF works by increasing proportionally to the number of times a word or a phrase appears in a document, but is offset by the number of documents that contain the word or phrase. When the TF-IDF score (weight) is higher, the word/phrase (type of analysis) is rarer, and vice versa. The most popular type of narrative analysis, with the highest TF-IDF, is discourse analysis. The next three positions (more than $10 \%$ of all cases) are occupied by thematic, content, and mixed-method approach. There are no such types of analysis as semiotic, performative, frame, visual, metaphor, or vignette (less than 3\% of all cases). These analyses are rather qualitative, which is why they seem to be more time-consuming. A detailed list of all types of narrative analysis is shown in Table 3.

Table 3. Extracted types of narrative analysis

\begin{tabular}{|c|c|c|c|c|c|}
\hline TYPE OF ANALYSIS & NO.CODES & $\%$ CODES & NO.CASES & $\%$ CASES & TF $\bullet$ IDF \\
\hline Discourse & 192 & $15,92 \%$ & 63 & $18,00 \%$ & 143 \\
\hline Thematic & 102 & $8,46 \%$ & 46 & $13,14 \%$ & 89,9 \\
\hline Content & 78 & $6,47 \%$ & 37 & $10,57 \%$ & 76,1 \\
\hline Mixed method & 83 & $6,88 \%$ & 37 & $10,57 \%$ & 81 \\
\hline Phenomenological & 52 & $4,31 \%$ & 36 & $10,29 \%$ & 51,4 \\
\hline Comparative & 59 & $4,89 \%$ & 27 & $7,71 \%$ & 65,6 \\
\hline Case & 35 & $2,90 \%$ & 24 & $6,86 \%$ & 40,7 \\
\hline Conversation & 75 & $6,22 \%$ & 24 & $6,86 \%$ & 87,3 \\
\hline Theoretical & 51 & $4,23 \%$ & 22 & $6,29 \%$ & 61,3 \\
\hline Hermeneutic & 56 & $4,64 \%$ & 19 & $5,43 \%$ & 70,9 \\
\hline Interaction & 33 & $2,74 \%$ & 15 & $4,29 \%$ & 45,1 \\
\hline Secondary & 48 & $3,98 \%$ & 15 & $4,29 \%$ & 65,7 \\
\hline Structural & 62 & $5,14 \%$ & 15 & $4,29 \%$ & 84,8 \\
\hline GTM & 24 & $1,99 \%$ & 14 & $4,00 \%$ & 33,6 \\
\hline Linguistic & 22 & $1,82 \%$ & 13 & $3,71 \%$ & 31,5 \\
\hline Biographical & 21 & $1,74 \%$ & 11 & $3,14 \%$ & 31,6 \\
\hline Collaborative & 18 & $1,49 \%$ & 11 & $3,14 \%$ & 27 \\
\hline Visual & 14 & $1,16 \%$ & 8 & $2,29 \%$ & 23 \\
\hline Semiotic & 19 & $1,58 \%$ & 7 & $2,00 \%$ & 32,3 \\
\hline Sequential & 35 & $2,90 \%$ & 7 & $2,00 \%$ & 59,5 \\
\hline Frame & 21 & $1,74 \%$ & 5 & $1,43 \%$ & 38,7 \\
\hline Metaphor & 38 & $3,15 \%$ & 5 & $1,43 \%$ & 70,1 \\
\hline Performative & 24 & $1,99 \%$ & 5 & $1,43 \%$ & 44,3 \\
\hline Taxonomic & 8 & $0,66 \%$ & 4 & $1,14 \%$ & 15,5 \\
\hline Network & 35 & $2,90 \%$ & 1 & $0,29 \%$ & 89 \\
\hline Vignette & 1 & $0,08 \%$ & 1 & $0,29 \%$ & 2,5 \\
\hline Total & 1206 & $100 \%$ & 472 & $135 \%$ & 56,2 \\
\hline
\end{tabular}

* Dialogic Analysis was included in the coding dictionary, but it does not have any occurrence. Source: Self elaboration. 
The aim of this paper is to provide a new proposition of the typology of narrative analysis approaches in the field of contemporary qualitative research practices based on data-driven approach. I did not want to create any heuristic, concept-driven approach that utilizes a more practical process (commonly referred as 'a rule of thumb' or 'best practice'), which is why I decided to use topic modeling, which is an unsupervised and explorative technique for detecting word/phrase patterns and automatically clustering word/phrase groups and similar expressions that best characterize a set of documents (corpus). The WordStat implements two methods of topic modeling: NNMF and Factor Analysis. The NNMF method uses non-negative matrix factorization to extract topics from a word-x-word cor- relation matrix computed by the WordStat, while Factor Analysis performs a similar extraction using a principal component analysis with the VARIMAX rotation. The NNMF method is faster and can handle larger matrices than factor analysis. It is, however, probabilistic in nature, yielding different, yet likely similar, solutions every time one runs it, while factor analysis will always produce the same results. I used the NNFM for the extracted twenty-six types of narrative analysis approaches. Moreover, I decided to validate the NNFM results of topic extraction with the Hierarchical Clustering method. All these exploratory analyses were done on the paragraph as the unit of analysis. The NNFM discovered five main topics which are internally differentiated by the Coherence index (see Table 4).

\section{Table 4. Topic modeling with Coherence index}

\begin{tabular}{|c|c|c|c|c|c|}
\hline TOPIC & TYPE OF ANALYSIS & COHERENCE & FREQ & CASES & $\%$ CASES \\
\hline 1 & Discourse I Conversation & 0,248 & 299 & 61 & $17,43 \%$ \\
\hline 2 & Vignette | Taxonomic I Frame | Theoretical & 0,322 & 52 & 17 & $4,86 \%$ \\
\hline 3 & Biographical | Case & 0,184 & 35 & 23 & $6,57 \%$ \\
\hline 4 & Visual | Semiotic & 0,244 & 15 & 8 & $2,29 \%$ \\
\hline 5 & Network | Structural | Sequential & 0,237 & 102 & 17 & $4,86 \%$ \\
\hline
\end{tabular}

Source: Self elaboration.

Topic Coherence is a measure used to evaluate results of topic modeling. It is a weighted average of the correlations of words (types of analysis) associated with the topic they create. In this model, top- ic coherence is small, which means that one has to carefully interpret these topics. The detailed summary of the topic modeling of narrative analysis is shown in Table 5. 
Table 5. Topic modeling results by the NNMF method

\begin{tabular}{|c|c|c|c|c|c|}
\hline TYPE OF ANALYSIS & TOPIC 1 & TOPIC 2 & TOPIC 3 & TOPIC 4 & TOPIC 5 \\
\hline Taxonomic & 0,66 & 0 & 0 & 0 & 0 \\
\hline Frame & 0,45 & 0 & 0 & 0 & 0 \\
\hline Theoretical & 0,37 & 0 & 0 & 0 & 0 \\
\hline Phenomenological & 0,26 & 0,03 & 0 & 0,24 & 0 \\
\hline Thematic & 0,22 & 0 & 0 & 0,16 & 0,01 \\
\hline Collaborative & 0,03 & 0 & 0 & 0 & 0 \\
\hline GTM & 0,02 & 0 & 0 & 0 & 0 \\
\hline Biographical & 0 & 0,75 & 0 & 0 & 0 \\
\hline Case & 0 & 0,74 & 0 & 0,01 & 0 \\
\hline Comparative & 0 & 0,13 & 0 & 0,12 & 0 \\
\hline Semiotic & 0 & 0 & 0,62 & 0 & 0 \\
\hline Secondary & 0 & 0 & 0,28 & 0 & 0 \\
\hline Content & 0,25 & 0,07 & 0,27 & 0 & 0 \\
\hline Mixed method & 0 & 0 & 0,26 & 0 & 0,03 \\
\hline Performative & 0 & 0 & 0,04 & 0 & 0 \\
\hline Conversation & 0 & 0 & 0 & 0,7 & 0 \\
\hline Discourse & 0 & 0 & 0 & 0,68 & 0 \\
\hline Linguistic & 0 & 0 & 0,17 & 0,26 & 0,06 \\
\hline Metaphor & 0 & 0 & 0 & 0,11 & 0,03 \\
\hline Network & 0 & 0 & 0 & 0 & 0,81 \\
\hline Structural & 0,15 & 0 & 0 & 0 & 0,78 \\
\hline Sequential & 0 & 0,09 & 0,08 & 0 & 0,37 \\
\hline Interaction & 0 & 0 & 0 & 0,18 & 0,21 \\
\hline Hermeneutic & 0 & 0 & 0 & 0,01 & 0,03 \\
\hline
\end{tabular}

* Extraction with NNMF by Paragraph (Loadings $>=0,30)^{12}$

* Vignette Analysis was excluded as it occurred only once.

Source: Self elaboration.

\footnotetext{
${ }^{12}$ In the topic extraction some control features - such as topic enrichment, checking for misspelling and topic weights - were included. Topic modeling consists of a series of words listed in descending order of topic specificity. The combined presence of those words in a text is used to identify whether a topic is present or not. This approach can result in an imprecise topic identification and measurement, since words often have multiple meanings and are often used in very different contexts. The topic enrichment allows one to go beyond bag-of-word approach by attempting to identify some phrases that are highly associated with the extracted topic, as well as other phrases that might represent exceptions and help disambiguate the various meanings of words. WordStat can identify potential misspellings of words in the topic that are part of any added or suggested phrases. This helps reduce the number of false negatives resulting from spelling errors in the original data set. Words in extracted topics are presented in descending order of relevance of specificity (weights) to the topic. When I use factor analysis for topic extraction, the weight of each word in a topic corresponds to its factor loading, while in the NNMF it corresponds to a coefficient obtained from the product of the $\mathrm{W}$ and $\mathrm{H}$ matrices.
} 
The NNMF topic modeling approach does not cover Riessman's heuristic typology, but helps to understand how different types of narrative analysis are related to each other and how they are grouped. The value of topic modeling is that results are data-grounded. The first topic consists of two groups: taxonomic, frame/theoretical, and phenomenological/thematic/content analysis. The second one is the case/biographical type of narrative analysis. The third one is disjointed into semiotic and secondary/content/mixed. The fourth one comprises discursive/conversational and linguistic/phenomenological types of analysis. The fifth one involves network/structural and sequential/interaction types of analysis. The other types of narrative analysis do not create any topics. Therefore, they have to be seen as separate narrative analysis approaches.
In order to get a clearer picture of the links between different types of narrative analysis and validate the received results of topic modeling, I used Hierarchical Clustering. This is a useful method of grouping types of narrative analysis according to their similarity into clusters; they are then displayed as a dendrogram (see Chart 2). When interpreting results, one looks for a set of clusters, where each cluster is distinct from another cluster, and the objects within each cluster are broadly similar to each other. I adopted this method when searching clusters in paragraphs with the so-called second profile classification and the Association Strength similarity index (the range is $0-1) .^{13}$

${ }^{13}$ Association Strength similarity index measures the cooccurrence of items while taking into account the possibility that two items will sometimes co-occur by chance.

\section{Chart 2. Dendrogram of cluster narrative analysis}

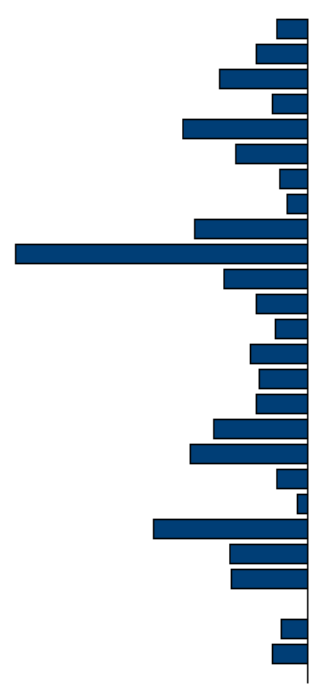
BIOGRAPHICAL_ANALYSIS
CASE_ANALYSIS
COMPARATIVE_ANALYSIS PERFORMATIVE_ANALYSIS MIXED_METHOD_ANALYSIS SECONDARY_ANALYSIS SECONDARY_ANALYSIS
SEMIOTIC_ANALYSIS SEMIOTIC_ANALYSIS
VISUAL_ANALYSIS CONVERSATION_ANALYSIS DISCOURSE_ANALYSIS HERMENEUTIC_ANALYSIS NETWORK_ANALYSIS LINGUISTIC_ANALYSIS METAPHOR_ANALYSIS INTERACTION_ANALYSIS

SEQUENTIAL_ANALYSIS

STRUCTURAL_ANALYSIS

CONTENT_ANALYSIS FRAME_ANALYSIS
TAXONOMIC_ANALYSIS THEMATIC_ANALYSIS PHENOMENOLOGICAL_ANALYSIS

THEORETICAL_ANALYSIS COLLABORATIVE_ANALYSIS GTM_ANALYSIS ing 
There are approximately five internally-cohered clusters on the dendrogram. To find a clearer interpretation of clusters, I used the Silhouette measure, which is a method of interpretation and validation of consistency within clusters (Table 6). The silhouette measures how an object is fixed to its own cluster (cohesion) compared to other clusters (separation). It ranges from -1 to +1 . A high value indicates that the object is well-matched to cluster and poorly-matched to other clusters. After doing a few tests, I got balanced clusters with an average Silhouette measure 0,77 and 0,3 cutting point of the association strength similarity index for hierarchical clustering.

Table 6. Silhouette measure of cluster cohesion

\begin{tabular}{|c|c|c|c|c|}
\hline TYPE OF ANALYSIS & CLUSTER & $\begin{array}{l}\text { SILHOUETTE } \\
\text { INDEX }\end{array}$ & $\begin{array}{l}\text { ALTERNATE } \\
\text { CLUSTER }\end{array}$ & $\begin{array}{l}\text { CLUSTER } \\
\text { SCORE }\end{array}$ \\
\hline COMPARATIVE & 3 & 0,70 & 8 & 0,54 \\
\hline PERFORMATIVE & 3 & 0,37 & 4 & \\
\hline SECONDARY & 4 & 0,97 & 9 & 0,76 \\
\hline SEMIOTIC & 4 & 0,84 & 8 & \\
\hline MIXED METHOD & 4 & 0,47 & 3 & \\
\hline NETWORK ANALYSIS & 8 & 0,88 & 9 & 0,67 \\
\hline LINGUISTIC ANALYSIS & 8 & 0,87 & 9 & \\
\hline HERMENEUTIC ANALYSIS & 8 & 0,82 & 9 & \\
\hline SEQUENTIAL ANALYSIS & 8 & 0,73 & 4 & \\
\hline INTERACTION ANALYSIS & 8 & 0,61 & 4 & \\
\hline METAPHOR ANALYSIS & 8 & 0,50 & 4 & \\
\hline STRUCTURAL ANALYSIS & 8 & 0,25 & 4 & \\
\hline FRAME ANALYSIS & 9 & 0,96 & 3 & 0,92 \\
\hline TAXONOMIC ANALYSIS & 9 & 0,96 & 10 & \\
\hline PHENOMENOLOGICAL ANALYSIS & 9 & 0,94 & 8 & \\
\hline THEORETICAL ANALYSIS & 9 & 0,94 & 10 & \\
\hline CONTENT ANALYSIS & 9 & 0,91 & 8 & \\
\hline VIGNETTE ANALYSIS & 9 & 0,87 & 8 & \\
\hline THEMATIC ANALYSIS & 9 & 0,84 & 8 & \\
\hline GTM ANALYSIS & 10 & 0,96 & 9 & 0,94 \\
\hline COLLABORATIVE ANALYSIS & 10 & 0,92 & 3 & \\
\hline
\end{tabular}

* Average Silhouette index $=0,77$.

* Only clustered types of Narrative Analysis are shown.

Source: Self elaboration. 
Both of these data-driven classification methods show that some types of narrative analysis are naturally connected in the field of qualitative research. Some clusters are partly similar to certain topics. Some types of narrative analysis exist independently. Each cluster or topic seems to be concentrated around one or two dominating types of narrative analysis. The contemporary field of narrative analysis resembles a kind of semantic network - with strong and weak connections between methods of lived experience analysis (see Chart 3) - in which clusters or topics temporarily exist as analytical synsets with nodal points. This is why clusters or topics can be seen as analytical subfields, which are created around epistemological approaches. In such a situation, it is really difficult to think about typology in the traditional way. This semantic network is a representation of thinking about narrative data analysis.

\section{Chart 3. Network representation of the typology of narrative analysis ${ }^{14}$}

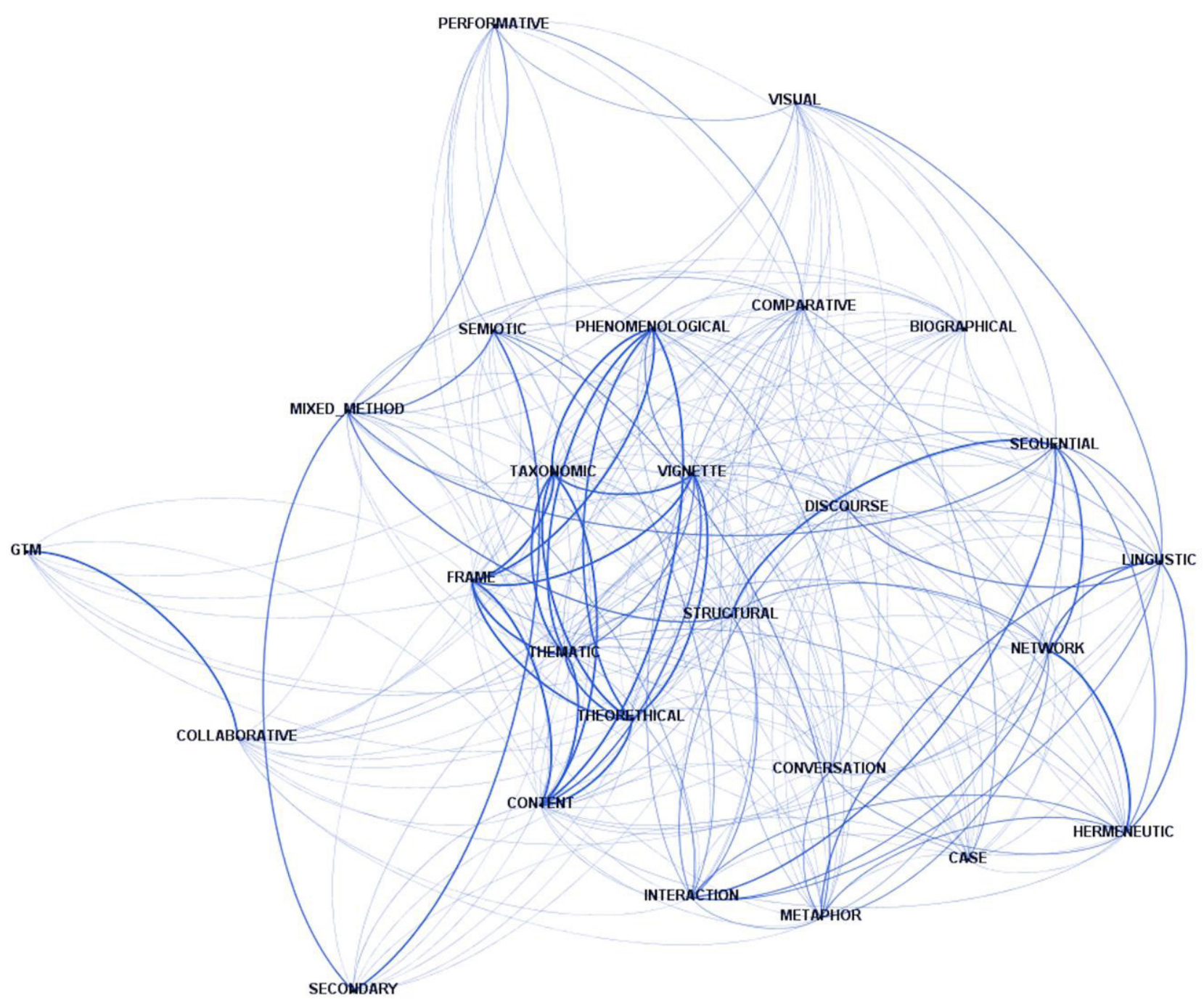

Source: Self elaboration.

${ }^{14}$ This network is based on hierarchical clustering similarity matrix among types of narrative analysis. 


\section{Discussion}

The corpus-based analysis, hierarchical clustering, and topic modeling approaches provide some general findings. There is no coherent and clear cluster or topic representation of types of narrative analysis in the contemporary field of qualitative research of lived experience. Rather, there are network connections between different types of narrative analysis. This is a reflection of what is happening in the present-day field of qualitative research methods, and what Norman K. Denzin and Yvonna S. Lincoln address as the still existing problem of the "curse of abundance" (Denzin and Lincoln 1994), and what is the key point of developing domain ontology (Bryda and Martini 2016). Multiparadigmacity and a scholar's creativity in qualitative research practices both make it difficult to do a comprehensive typology of narrative analyzes. Typology is a normative, mental construct, which, on the one hand, allows one to obtain an ordered and synthetic picture of the studied reality - or allows for a further analysis and, on the other hand, makes it possible to simplify the reality when creating a typology. The typologies created heuristically are embedded in epistemological approaches more than the real world of research practices. I believe that data-grounded typology provides a more complete picture of the field of narrative analysis than any mentally constructed distinctions do. Of course, the existing typology/ies is/are useful in building coding dictionaries (e.g. Riessman's typology of narrative analysis), but should be enriched by an exploratory analysis of different qualitative corpora. I believe that exploratory data analysis is an important step in creating the comprehensive typology of narrative analyses. Because of taking into account a variety of qualitative research methods and techniques, constructing typology in the traditional way does not make much sense. By using new approaches - such as dictionary-based coding, text mining, and exploratory analysis -one can go deeper into the field of narrative analysis and see how different analytical approaches are linked together, and how scholars use them in their research practice.

A narrative analysis literature review and a corpus-based text mining analysis both show that if one wanted to do any typology of narrative analysis, they would have to take into account what kind of data has been collected and how to think of this data, since different narrative analyses follow different narrative data types. There is no causal relationship but, rather, abductive reasoning. There are two axes - narrative analysis and narrative data - that create a conceptual, two-dimensional space. The analysis axe is based on the distinction between socio-linguistic and socio-cultural analytical data approaches (Grbich 2013). The socio-linguistic frame focuses on "plots" or the structure of narratives, and how they convey meaning. The text and the sequence of events is a main point of interest here. One pays less attention to the interactions between the actor/s and the audience, the power relations, the shifts in meaning, the co-construction of meaning, and the impact of narratives on the listener. The assumption that language represents the reality does not take into account the arguments that language is biased, embedded in socio-cultural contexts, and that it constructs our reality. As Carol Grbich points out, narratives are complex constructions of meaning, linking personal lives, community, and culture, and as such should be preserved intact, not fractured. One cannot ignore the influence of cultural contexts and the impact of social factors such as race, class, gender, education, or hierarchy. Narratives can follow a chronological sequence through time in a non-linear way; they can be 
linked by themes which are not necessarily sequential. The socio-cultural approach to narrative analysis goes beyond the structural language analysis of the sociolinguistic approach in order to identify broader interpretive frameworks that people use to make sense of everyday life and particular events. The socio-cultural narrative analysis focuses on the stories told by research participants in specific contexts. The story consists of many lived experiences or social events that are meaningful to the participants. This means that stories are complete, having a beginning, a main body, and an ending, so it is difficult to reduce contextually-created meanings to structurally-ordered plots. According to social sciences, people communicate with each other through stories, and stories are typically gathered in research through oral histories or face-to-face interviews. When one loses broader interpretive frameworks used by both the participant and the researcher, one loses the sense of particular incidents in the individuals' lives.

The second distinction concerns a way in which data/stories are collected, as well as data perception in narrative analysis. According to the social-sciences methodology, stories can be gathered in two ways, i.e. primarily (the research process) or secondarily (the existing sources such as written diaries, interview transcriptions, social archives, Internet sites, etc.). More important is the fact that the matter is strictly connected with the way of treating narratives as a source of knowledge about our worldview. Stories can be perceived in the positivist way - i.e. as social facts that occur naturally - or in the interpretivist way - i.e. as psychological facts that are social constructions. The naturalistic approach in narrative inquiry is the process of describing and understanding stories as they occur in their natural contexts. They are real such as they were told. One considers them as the naturalistic data, because it is believed that it is neither elicited nor affected by the intentional actions of social researchers. There is the epistemological correspondence between the participant's lived experience and its language representation. The story is just a story. The story is a real representation of lived experience. In the case of the constructivist approach, one can say that stories are naturally constructed and there is no such ontological correspondence as the one mentioned above. The story is a social construction, because the human language apparatus is unable to describe the essence and the sense of lived experience. Due to the linguistic imperfections, people are only able to create specific linguistic constructs which are socio-culturally (contextually) embedded. The living world is based on the close relationship between language and culture, and our cognitive categories. The narratives that one analyzes are culturally grounded; in order to understand them one has to go beyond the structural linguistic analysis. ${ }^{15}$ These socio-cultural/socio-linguistic dimensions and the constructivist/naturalistic data approaches are conceptual frames which can be useful for understanding the network typology of narrative analysis.

\section{Conclusion}

It seems that developing a comprehensive network typology must be a synthesis of top-down and bottom-up approaches, and should be open to any variations and combinations in the field of narrative analysis. Building this kind of typology, one has to use current achievements from other disciplines - CAQDAS and Digital Humanities innovations,

\footnotetext{
${ }^{15}$ Of course, this distinction does not refer to the naturalistic assumption of the holistic nature of reality, or to the constructivist plurality of the reality of everyday life.
} 
Corpus Linguistics, Big Data, Informatics, and Data Science - to overcome human cognitive limitations. The use of the linguistic knowledge of semantics, pragmatics, and the logic of relationships between elements of written statements - in combination with techniques from the Natural Language Processing and Text Mining - is a new approach not only in the field of computer-assisted qualitative data analysis (Ho Yu, Jannasch-Pennell, and Di Gangi 2011; Wiedemann 2013; Bryda 2014a), but also

\section{References}

Andrews, Molly et al. 2004. “Narrative research.” Pp. 98-113 in Qualitative Research Practice, edited by C. Seale et al. London: Sage Publications.

Berelson, Bernard. 1952. Content analysis in communication research. Glencoe: Free Press.

Bernard, Russell H. and Gerry W. Ryan. 2010. "Content analysis." Pp. 287-310 in Analyzing Qualitative Data: Systematic Approaches, edited by B. Russell and G. Ryan. Los Angeles: Sage Publications.

Berry, Michael W. 2004. Survey of Text Mining: Clustering, Classification, and Retrieval. New York: Springer.

Bong, Sharon A. 2002. “Debunking Myths in Qualitative Data Analysis."Forum Qualitative Sozialforschung 3(2). Retrieved May 5, 2020 (https://www.qualitative-research.net/index.php/fqs/article/view/849).

Bowker, Lynne and Jennifer Pearson. 2002. Working with Specialized Language: A Practical Guide to Using Corpora. London: Routledge.

Bryda, Grzegorz. 2014a. "Caqdas, Data Mining i odkrywanie wiedzy w danych jakościowych." Pp. 13-40 in Metody i techniki odkrywania wiedzy. Narzedzia CAQDAS w procesie analizy danych jakościowych, edited by J. Niedbalski. Lodz: Wydawnictwo Uniwersytetu Łódzkiego. in developing a typology of narrative analysis. This perspective is derived from the traditional method of content analysis, but it is less time-consuming and its solutions can be used in the analysis of contents not yet explored. Using the corpus linguistics and dictionary-based approach in a text-coding process allows one to not only quickly and comprehensively analyze large data volumes, but also open researchers to computational innovations in the process of qualitative data analysis.

Bryda, Grzegorz. 2014b. “CAQDAS a badania jakościowe w praktyce." Przeglad Socjologii Jakościowej 10(2):12-38.

Bryda, Grzegorz. 2020. "From CAQDAS to Text Mining: The Domain Ontology as a Model of Knowledge Representation About Qualitative Research Practices." Pp. 72-88 in Computer supported qualitative research: new trends on qualitative research, edited by P. Costa Antonio, P. Reis Luis, and A. Moreira. WCQR2019. Cham: Springer International Publishing.

Bryda, Grzegorz and Natalia Martini. 2016. “W stronę ontologii pola badań jakościowych."Przeglad Socjologii Jakościowej 12(4):24-40.

Bryda, Grzegorz and Krzysztof Tomanek. 2014. “Od Caqdas do Text Miningu. Nowe techniki w analizie danych jakościowych." Pp. 191-218 in Metody i techniki odkrywania wiedzy. Narzędzia CAQDAS w procesie analizy danych jakościowych, edited by J. Niedbalski. Lodz: Wydawnictwo Uniwersytetu Łódzkiego.

Cheng, Winnie. 2012. Exploring Corpus Linguistics: Language in Action. London: Routledge.

Clandinin, Jean D. and Jerry Rosiek. 2007. "Mapping a landscape of narrative inquiry: Borderland spaces and tensions." Pp. 35-76 in Handbook of narrative inquiry: Mapping a methodology, edited by Jean D. Clandinin. Thousand Oaks: Sage Publishing. 
Collins, Kathleen M.T., Anthony J. Onwuegbuzie and Jiao G. Qun. 2007. "A mixed methods investigation of mixed methods sampling designs in social and health science research." Journal of Mixed Methods Research 1(3):267-294.

Cortazzi, Martin. 1993. Narrative Analysis. London: Falmer Press.

Cortazzi, Martin. 2001. "Narrative Analysis in Ethnography." Pp. 384-394 in Handbook of Ethnography, edited by P. Atkinson et al. London: Sage Publications.

Coulter, Cathy A. and Mary Lee Smith. 2009. "The Construction Zone: Literary Elements in Narrative Research. "Educational Researcher 38(8):577-590.

Creswell, John W. 1998. Qualitative inquiry and research design: Choosing among five traditions. Thousand Oaks: Sage Publications.

Creswell, John W. 2015. A Concise Introduction to Mixed Methods Research. London: SAGE.

Czarniawska-Joerges, Barbara. 2004. Narratives in social science research. Los Angeles: Sage Publications.

De Fina, Anna and Alexandra Georgakopoulou. 2015. The Handbook of Narrative Analysis. London: Wiley-Blackwell.

Denzin, Norman K. and Yvonna S. Lincoln. 1994. Handbook of Qualitative Research. Thousand Oaks: Sage Publications.

Denzin, Norman K. and Yvonna S. Lincoln. 2011. The SAGE Handbook of Qualitative Research. Fourth Edition. Thousand Oaks: Sage Publications.

Dey, Ian. 1993. Qualitative data analysis: A user-friendly guide for social scientists. London, New York: Routledge.

Elliott, Jane. 2009. Using narrative in social science research: Qualitative and quantitative approaches. London: Sage Publications.

Feldman, Ronen and James Sanger. 2007. The Text Mining Handbook: Advanced Approaches in Analyzing Unstructured Data. Cambridge, MA: Cambridge University Press.

Fielding, Nigel. 2012. "The Diverse Worlds and Research Practices of Qualitative Software." Forum Qualitative Sozialforschung 13(2). Retrieved February 5, 2020 (https://www.qualitative-research.net/index.php/fqs/article/view/1845).
Fielding, Nigel G. and Raymond M. Lee. 1998. Computer Analysis and Qualitative Research. London: SAGE.

Flick, Uwe. 2014. The SAGE Handbook of Qualitative Data Analysis. Los Angeles: Sage Publications.

Flick, Uwe. 2018. The SAGE Handbook of Qualitative Data Collection. Los Angeles: Sage Publications.

Gee, James Paul. 1991. "A linguistic approach to narrative." Journal of Narrative and Life History 1(1):15-39.

Goffman, Erving. 1975. The presentation of self in everyday life. Harmondsworth: Penguin Books.

Grbich, Carol. 2013. Qualitative data analysis: An introduction. Los Angeles: Sage Publications.

Herman, Luc and Bart Vervaeck. 2005. Handbook of Narrative Analysis. Frontiers of narrative. Lincoln, NE: University of Nebraska Press.

Ho, Yu Chong, Angel Jannasch-Pennell, and Samuel DiGangi. 2011. “Compatibility Between Text Mining and Qualitative Research in the Perspectives of Grounded Theory, Content Analysis, and Reliability." The Qualitative Report 16(3):730-744.

Holstein, James A. and Jaber F. Gubrium. 2012. Varieties of Narrative Analysis. Los Angeles: Sage Publications.

Hopkins, Daniel J. and Gary King. 2010. “A method of automated nonparametric content analysis for social science."American Journal of Political Science 54(1):229-247.

Ignatow, Gabe, and Rada Mihalcea. 2017. Text Mining: A Guidebook for the Social Sciences. London: Sage publication.

Kelle, Udo. 1995. Computer-aided qualitative data analysis: Theory, methods and practice. London: Sage Publications.

Kohler Riessman, Catherine. 1993. Narrative Analysis. Newbury Park: Sage Publications.

Kohler Riessman, Catherine. 2008. Narrative Methods for the $\mathrm{Hu}$ man Sciences. Los Angeles: Sage Publications.

Kreiswirth, Martin. 2005. "Narrative Turn in the Humanities." Pp 377-382 in Routledge Encyclopedia of Narrative Theory, edited by D. Herman, J. Manfred, and R. Marie-Laure. London: Routledge. 
Krippendorf, Karl. 2004. Content analysis: An introduction to its methodology. Thousand Oaks: Sage Publications.

Labov, William. 1972. Language in the Inner City. Philadelphia: University of Pennsylvania Press.

Labov, William. 1991. Sociolinguistic patterns. Philadelphia: University of Pennsylvania Press.

Labov, William and Joshua Waletzky. 1967. "Narrative Analysis." Pp. 12-44 in Essays on the Verbal and Visual Arts, edited by J. Helm. Seattle: University of Washington Press.

Leetaru, Kalev. 2012. Data Mining Methods for the Content Analyst: An Introduction to the Computational Analysis of Content. Park Drive: Taylor and Francis.

Lewins, Ann and Christina Silver. 2007. Using Software in Qualitative Research: A Step-by-Step Guide. Thousand Oakes: Sage Publications.

Mayring, Philipp. 2000. “Qualitative Content Analysis.” Forum Qualitative Sozialforschung 1(2). Retrieved March 5, 2020 (https://www.qualitative-research.net/index.php/fqs/article/ view/1089/2385).

McEnery, Tony and Andrew Hardie. 2011. Corpus Linguistics: Method, Theory and Practice. Cambridge, MA: Cambridge University Press.

McEnery, Tony and Andrew Wilson. 2001. Corpus Linguistics: An Introduction. Edinburgh: Edinburgh University Press.

Mehdi, Raza Ali. 2016. The Routledge Encyclopedia of Research Methods in Applied Linguistics. Basingstoke: Taylor \& Francis Ltd.

Mishler, Elliot G. 1995. "Models of Narrative Analysis: A Typology."Journal of Narrative and Life History 5(2):87-123.
Munn, Katherine and Barry Smith. 2008. Applied Ontology: An Introduction. Piscataway: Transaction Books Rutgers University.

Phoenix, Cassandra, Brett Smith, and Andrew C. Sparkes. 2010. "Narrative analysis in aging studies: A typology for consideration." Journal of Aging Studies 24(1):1-11.

Polanyi, Livia. 1985. Telling the American story: A structural and cultural analysis of conversational storytelling. Norwood, NJ: Ablex Publishers.

Polkinghorne, Donald E. 1988. Narrative knowing and the human sciences. New York: State University of New York.

Schreier, Margit. 2012. Qualitative Content Analysis in Practice. London: Sage Publications.

Tashakkori, Abbas and Charles Teddlie. 1998. Mixed methodology: Combining qualitative and quantitative approaches. Thousand Oaks: Sage Publications.

Tomanek, Krzysztof and Grzegorz Bryda. 2014. “Odkrywanie wiedzy w wypowiedziach tekstowych. Metoda budowy słownika klasyfikacyjnego." Pp. 219-248 in Metody i techniki odkrywania wiedzy. Narzędzia CAQDAS w procesie analizy danych jakościowych, edited by J. Niedbalski. Lodz: Wydawnictwo Uniwersytetu Łódzkiego.

Wiedemann, Gregor. 2013. “Opening up to Big Data: Computer-Assisted Analysis of Textual Data in Social Sciences." Forum Qualitative Sozialforschung 14(2). Retrieved January 12, 2020 (https://www.qualitative-research.net/index.php/fqs/article/ view/1949).

Wolfson, Nessa. 1976. "Speech Events and Natural Speech: Some Implications for Sociolinguistic Methodology."Language in Society 5(2):189-209.

\section{Citation}

Bryda, Grzegorz (2020) “Whats and Hows? The Practice-Based Typology of Narrative Analyses." Przegląd Socjologii Jakościowej 16(3):120-142. Retrieved Month, Year (www.przegladsocjologiijakosciowej.org). DOI: http://dx.doi.org/10.18778/17338069.16.3.08 


\section{Co i jak? Typologia analiz narracyjnych oparta na praktykach badawczych}

Abstrakt: Istotą jakościowych praktyk badawczych jest wieloparadygmatyczność, która rodzi współistnienie różnych podejść metodologicznych w analizie i badaniu ludzkich doświadczeń w świecie życia codziennego. Różnorodność ta jest szczególnie widoczna w dziedzinie badań i analizy danych narracyjnych. Celem artykułu jest refleksja metodologiczna nad tworzeniem typologii analiz narracyjnych i zarazem propozycja nowego sposobu typologizacji podejść analitycznych, opartego na łączeniu lingwistyki korpusowej i przetwarzania języka naturalnego z procedurami CAQDAS, analizy treści i Text Mining. Typologia ta jest oparta na analizie narracyjnych praktyk badawczych odzwierciedlonych w języku anglojęzycznych artykułów opublikowanych w pięciu uznanych na świecie jakościowych czasopismach metodologicznych w latach 2002-2016. W artykule wykorzystuję metodę słownikową w procesie kodowania artykułów, hierarchiczne grupowanie i modelowanie tematyczne w celu odkrywania w tych publikacjach różnych typów analiz narracyjnych i badania relacji semantycznych między nimi. Jednocześnie konfrontuję heurystyczną typologię Riessmana z podejściem opartym na lingwistyce i eksploracji danych w celu rozwijania spójnego obrazu metodologii analizy narracyjnej we współczesnej dziedzinie badań jakościowych. Ostatecznie przedstawiam nowy model myślenia o analizie narracyjnej.

Słowa kluczowe: analiza narracyjna, CAQDAS, analiza treści, Text Mining, kodowanie słownikowe, modelowanie tematyczne 